\title{
OPEN EDUCATIONAL RESOURCES \\ BASED ONLINE TUTORIAL MODEL FOR DEVELOPING CRITICAL THINKING OF HIGHER DISTANCE EDUCATION STUDENTS
}

\author{
Dr. Ucu RAHAYU \\ Faculty of Education \\ Universitas Terbuka \\ Jakarta, Indonesia \\ Dr. Amalia SAPRIATI \\ Faculty of Education \\ Universitas Terbuka \\ Jakarta, Indonesia
}

\section{ABSTRACT}

This paper aims to develop a prototype of learning for the achievement of critical thinking skills of Higher Distance Education students through the utilization of open educational resources (OER). It is based on a research and development project conducted from September 2013 until April 2014 at Universitas Terbuka (UT), the Indonesia Open University. The research consisted of three stages. The first stage developed the Tutorial Activity Plan (TAP) and the Tutorial Activity Unit (TAU). The second stage developed a prototype online tutorial model along with the initiation materials and tasks. The third stage was a trial implementation of online tutorials using OER. The Online tutorials were a course called Natural Resource Conservation and Environment (NRCE). Data on student learning outcomes on the completion of tasks and discussion activities were collected. Student learning outcomes were based on indicators of Enis's critical thinking skills. Student perceptions toward online tutorial activities were based on the students' assessment of the online tutorial implementation. Data were collected using a questionnaire, tests, document analysis forms, and interviews. The results indicated that critical thinking can be develop through the utilization online tutorial activities. The students utilized OER as reference source when they were engaging in online tutorial tasks and online discussions. Critical thinking skills of the students could be evaluated based on student learning outcomes, e.g. student discussions and answering questions while undertaking online tutorial tasks.

Keywords: Online tutorials, conservation of natural resources, digital teaching materials.

\section{INTRODUCTION}

According to a $21^{\text {th }}$ century partnership learning framework, the expertise that humans must have in the $21^{\text {st }}$ century, includes critical thinking skills. Osborn (2007) also included critical thinking skills in his recommendation concerning science education for the 21st century. Critical thinking skills can help students avoid mistakes in connecting new concepts prior to knowledge, so they can prevent misconceptions among students (Kogut, 1996).

Critical thinking skills are also one of the competencies that must be achieved in lectures according to Natural Resources Conservation and Environment (NRCE). The largest sea 
area $\left(5.8\right.$ million $\left.\mathrm{km}^{2}\right)$ and the largest number of islands $(17,508)$, Indonesia enjoys extraordinary natural resources. The nation is home to $37 \%$ of the world's species, $30 \%$ of the world's mangroves, and $\mathbf{1 8 \%}$ of the world's coral reefs. Its tropical forests act as the lungs of the world (Hertzmark in National Education Standards Body, 2013). However, it has been experiencing slow but systematic natural and environmental degradation. Critical thinking skills are needed in addressing this environmental problem.

UT is one of the distance higher education institutions in Indonesia utilizing the internet to provide services to its students. UT has used Moddle as a Learning Management System (LMS) that supports academic activities including online tutorials for all its courses, with the exception of practical courses. The tutors are qualified lecturers or practitioners from state universities drawn, from UT, private universities, relevant business, industries and private sectors. The ability to think critically expected to be owned by both students who study through face to face as well online. According to Risch, Jackson, and Murray (2013), the implementation of Web 2.0 applications on online discussion can improve critical thinking skills. Utilization of discussion board tools (Hibbard, Bellara, and Vermette, 2010) in particular, very useful. Likewise, through science news on the internet, students can increase critical thinking and argumentation skills (Lin, 2013).

OER is a set of teaching/learning materials, residing in the public domain that has been released under an intellectual property license to be used free of charge or adapted by others (UNESCO, 2009). The rapid growth of OER has provided new opportunities for teaching and learning. Digitized OER materials can be offered freely and openly for educators, students and learners to use in teaching, learning and research (Bissell, 2009). Utilization of OER in learning helps enrich lessons. OER can be text, video, audio, images, and more. However, at the time of processing and interpreting various information sources from the internet or any other source, a student must have the ability to select and evaluate them.

\section{CRITICAL THINKING SKILLS}

According to Basham et al. (2008) critical thinking is a set of cognitive skills and intellectual dispositions necessary to identify, analyze and evaluate arguments, formulate and present convincing reasons that support conclusions, and to make rational and appropriate decisions. Critical thinking is a reflective and sensible thought that focuses on determining what to believe or do (Ennis, 1985). Sternberg (1986) defines critical thinking as the mental process, strategy, and representation that people use to solve problems, make decisions, and learn new concepts.

Ennis (1996) identified 12 indicators of critical thinking skills that could be grouped into five groups of thinking skills namely:

$>$ Providing a simple explanation: a) focusing questions, b) analyzing arguments, and c) asking and answering questions about an explanation or challenge;

$>$ Building basic: a) considering the credibility of the source, b) observing and considering observations;

$>$ Concluding, which includes: a) making deductions and considering the results of deductions, b) making inductions and considering the results, c) making decisions and considering results;

$>$ Providing further explanation: a) defining terms and considering definitions, b) identifying assumptions; and

$>$ Setting strategies and tactics: a) deciding on an action, and b) interacting with others.

Likewise, Norris and Ennis argue that critical thinking is a sensible and reflective thinking ability that is focused on making decisions about what is done or is believed (Stiggins, 
1994). Thinking critically is a thinking mode that is directed to the goal. The goal of critical thinking is to evaluate the best acts or beliefs.

Experts define critical thinking skills as the ability to analyze arguments, claim, and prove a concept or theory based on evidence (Ennis, 1985, Facione, 1990; Halpern, 1998; Paul, 1992); make conclusions by using inductive and deductive abilities (Ennis, 1985; Facione, 1990; Paul, 1992; Willingham, 2007); as well as making decisions or solving problems (Ennis, 1985; Halpern, 1998; Willingham, 2007). Other capabilities or behaviors relevant to critical thinking include asking and answering questions to clarify a problem (Ennis, 1985); defining terms (Ennis, 1985); identifying assumptions (Ennis, 1985; Paul, 1992); interpreting and explaining a concept (Facione, 1990). Factors that can improve students' critical thinking skills in online lectures include online discussions using the four questions proposed by Alexander et.al. (2010), application of Web 2.0 (Risch, Jackson, \& Murray, 2013), the use of discussion board tools (Hibbard, Bellara, \& Vermette, 2010), and delivering arguments and evaluating science news on the internet (Lin, 2013).

Halpern (1998) developed two learning programs aimed at improving critical thinking skills and student abilities. Use of a general problem-solving strategy, has been found to be of help in increasing students' cognitive development. Students taught with specific problem-solving strategies can demonstrate mental mathematics that are more akin to expert skills. He argues that teaching, "broad-based, interdisciplinary" thinking skills, is the most effective way to teach critical thinking. Critical thinking skills are not a direct focus of learning, but a natural consequence because they are involved with the subject matter (Ennis, 1989).

Case (2005) argues that critical thinking is a tool useful in teaching the content and skills contained in the curriculum. Ennis (1989) suggests that critical thinking skills can be loaded into common components and certain specific components of learning. According to Facione (1990) critical thinking can be taught in the context of specific content, or content taken from "events in everyday life". Paul (1992) recommends training in basic critical thinking skills and which are integrated into specific disciplines. Other researchers recommend the use of certain learning strategies such as explicit teaching, cooperative learning, modeling, and constructivist techniques to foster the development of critical thinking skills and abilities.

\section{OPEN EDUCATIONAL RESOURCES (OER)}

Open Educational Resources (OER) consist of digitized materials offered freely and openly for educators, students and self-learners to use and re-use for teaching, learning and research. An Open Educational Resource is a learning resource or teacher support material as well as other resources used to ensure the quality of education and educational practices (Johnstone, 2005). According to Kanwar and Uvalic-Trumbic (2011), OER is defined as a source of education that has content licenses in the form of streaming video, paper-based text, video, audio or multimedia computer-based openly available to educators as well as students and designed to support learning activities.

Bissell (2009) notes that Open Educational Resources (OER) represents an international effort to equalize access and opportunity of knowledge and education around the world. OER is a knowledge resource that is in the public domain and can be used for free by anyone. It is offered in digital form freely and openly to anyone to be utilized in the learning process or research. The possibility of loss of property or copyright in OER due to the use or utilization by others may occur. To have ownership, a person or institution may join the Creative Commons and Open Course Ware Consortium. Information and communication technology can be used to make information available since many learning resources such as web portals containing educational materials have already been created. Some characteristics of OER are 1) Free materials, 2) sustainable access to resources, 3) the ability to pursue the topic thoroughly; 4) the ability to learn for personal knowledge or enjoyment; and 5) easy access to materials (Arendt and Shelton, 2009). 
OER has at least three elements, 1) the content of learning materials or references, 2) the equipment in software form for the development and delivery of learning resources, and 3) a standard or convention to publish digital open source (D 'Anthony, 2006).

\section{PURPOSE}

The overall purpose of this study is to come up with a prototype online tutorial model of NRCE course which can train students' critical thinking skills by using open educational resource. Specifically, it aims to (1) develop the kit containing online tutorial materials for the course of NRCE utilizing open education resource (OER), including utilizing OER as additional learning material and resource of discussion; (2) analyze implementation of the online tutorial developed utilizing OER by identifying (a) the number participation of the students, (b) the utilization of OER in online tutorial, (c) achievement of students' critical thinking, and (d) student perceptions toward implementation of OER based online turorial

\section{METHODOLOGY}

The method employed is a research and development by using qualitative-quantitative approach and was conducted between October 2013 and April 2014. We developed and validated the products used in learning (Borg and Gall, 1989). The study was conducted in three (3) stages. The first stage consisted of a preliminary study made up of a subject competency analysis, the development of an Activity Tutorial, a Tutorial Unit and an analysis of bibliography sources. The second phase consisted of prototype development of the online tutorial model, which included the development of initiation materials and tasks to trigger library searching through OER, the development of student guidance in using OER, preparation of the Learning Management System (LMS) platform in accordance with online tutorial design, and an expert evaluation of prototype model. The third stage of consisted of the implementation of online tutorials by utilizing materials that have been developed and formative evaluation of learning models that have been developed.

The course selected, Natural Resource Conservation and Environment (NRCE), focused on the fast changing global environment needed in-depth analyses and learning. The data collection techniques used included documentation, questionnaires, tests, and interviews. The data were analyzed using qualitative and descriptive approach. The kit of online tutorial material was developed through literature review of some OERs. Content validity of the tutorial kit was established on the basis of expert reviews, the on tutorial activity plan (TAP), the tutorial activity unit (TAU), the online tutorial materials and tasks, and a literature review. In online tutorial activities, the students were given the resource addresses or sometimes not even given any addresses so that they can search for them directly. During discussions, the students were also given assignments. They could search for the answers refer to OER.

Formative evaluation of the implementation of online tutorials was obtained through a questionnaire. Questions used in the questionnaire included access to articles through open education resources, ease in analyzing readings, online interaction skills, and collaborative skills in building discussions. Student learning outcomes are usually based on competency achievement that indicate critical thinking ability. The Ennis indicator was used to assess critical thinking ability. Students' answers were determined evaluated based on the achievement of a predetermined competency in accordance with the "marking scheme". All data were analyzed descriptively qualitative. 


\section{PRESENTATION OF THE RESULTS}

Development of Online Tutorial Materials Utilizing Open Education Resource (OER)

Development of Tutorial Activity Plan (TAP) and Tutorial Activity Unit (TAU) Utilizing OER

The design of an online tutorial model through OER utilization begins with the development of the TAP and TAUs. A TAP is a design of tutorial activities that will be implemented for one semester / period of online tutorial. TAUs represent the implementations from TAP; they contain tutorial event units to be used during weekly online tutorial meeting. The TAP and the TAUs contain competencies that should be achieved by students after participating in online tutorials. For each course, one TAP, 8 TAUs, 8 material initiations, and 3 assignments were developed. All these used as references in developing the prototype of the OER based online learning model for the Conservation of Natural Resources and Environment (NRCE) course. The TAP and TAUs prepared for NRCE online tutorial were adapted from several existing TAP and TAUs for NRCE face-to-face tutorials. As for the TAP, the learning resource columns were filled by the subject material, reference books and OER. OER includes videos as well as website address. Each TAP included the general and special goals of the online tutorial, time allocation, learning resource / media and the details of online tutorial activities performed during preliminary, core, and closing activities. The main subject references and OER was listed in the learning resource/media of TAP.

\section{Utilization of OER as Additional Learning Material and Resource of Discussion}

During online tutorial activities, tutors utilize open educational resources (OERs) in addition to the basic learning material as teaching materials. The utilization of OER as learning material is usually done in the fifth and sixth weeks. In the previous weeks, tutors provided material that could be classified as basic learning materials. However, tutors encouraged students to seek other learning resources as an enrichment from OER during discussion or tutorial assignment. The utilization of OER as learning material during online tutorial as clearly show in Table 1.

Table 1. Utilization of OER as Additional Learning Material, Learning Resource of Discussion and Assignment

\begin{tabular}{|c|c|c|c|c|}
\hline \multirow[t]{2}{*}{ Week } & \multirow[t]{2}{*}{ Topics } & \multicolumn{3}{|c|}{ Utilization of OER as } \\
\hline & & $\begin{array}{l}\text { additional } \\
\text { learning } \\
\text { material }\end{array}$ & $\begin{array}{l}\text { learning } \\
\text { resources for } \\
\text { the } \\
\text { discussion }\end{array}$ & $\begin{array}{l}\text { Learning } \\
\text { resources for } \\
\text { the } \\
\text { assignment }\end{array}$ \\
\hline 1 & $\begin{array}{l}\text { Basic principle of } \\
\text { Conservation and } \\
\text { Natural Resource and } \\
\text { Environment }\end{array}$ & & available & \\
\hline 2 & $\begin{array}{l}\text { Conservation of water } \\
\text { resources }\end{array}$ & & available & \\
\hline 3 & $\begin{array}{l}\text { Conservation of land } \\
\text { resources }\end{array}$ & & available & available \\
\hline 4 & $\begin{array}{l}\text { Conservation of air } \\
\text { resources }\end{array}$ & available & available & \\
\hline 5 & $\begin{array}{l}\text { Conservation of } \\
\text { energy resources }\end{array}$ & available & available & \\
\hline 6 & $\begin{array}{l}\text { Conservation of } \\
\text { energy resources }\end{array}$ & available & available & \\
\hline 7 & $\begin{array}{l}\text { Factors influencing } \\
\text { conservation and } \\
\text { natural resources }\end{array}$ & & available & available \\
\hline 8 & $\begin{array}{l}\text { Factors influencing } \\
\text { conservation and } \\
\text { natural resources }\end{array}$ & & available & \\
\hline
\end{tabular}


Implementation of the online Tutorial Utilizing Open Education Resource (OER) The Number of Participation

Out of the 124 students registered to the NRCE course, 33\% registered as online tutorial students. As many as $\mathbf{2 8}$ students activated and accessed online tutorials. The details are presented in Figure 1.

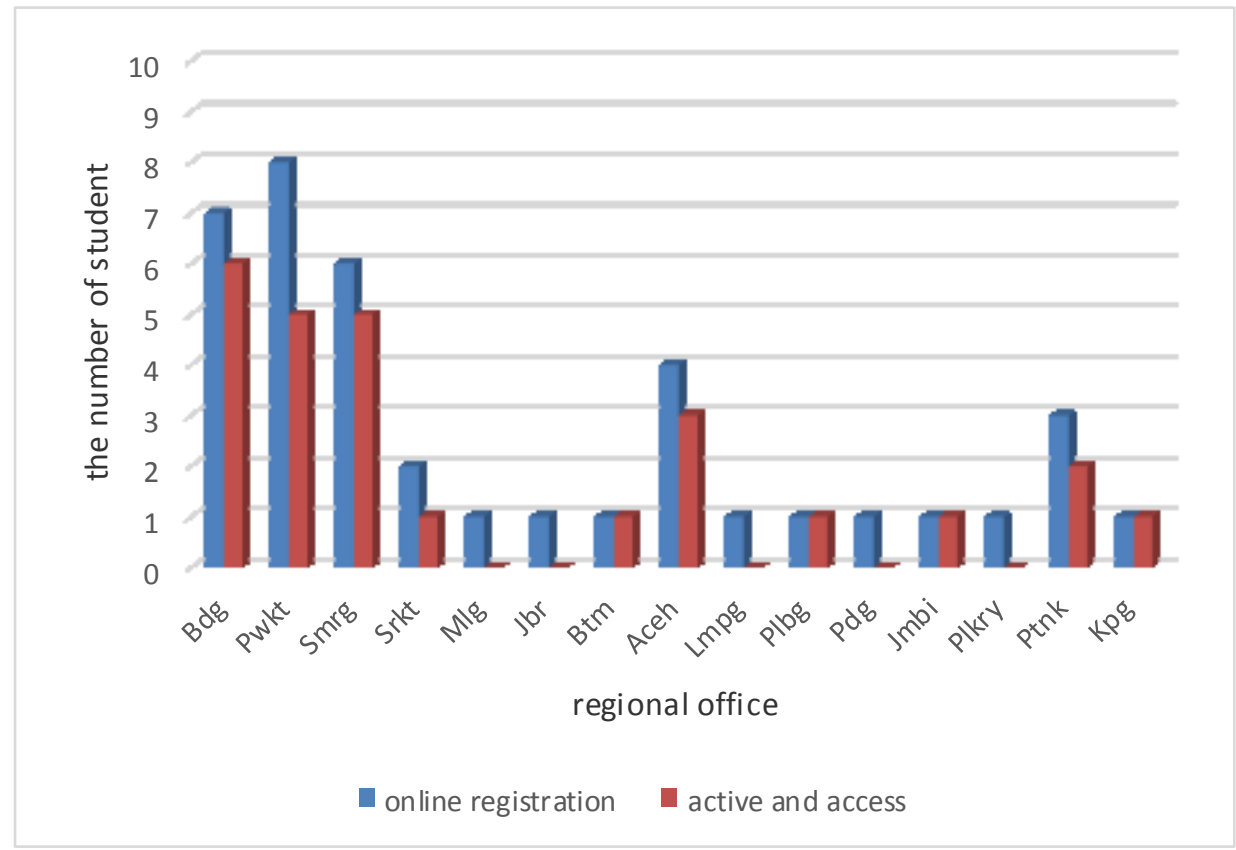

Figure 1. Number of Students Completing Online Registration and Remained Active at Each Regional Office (RO)

The Students who had actively accessed the online tutorial were spread across 15 regional offices (RO). The students who did so most actively were from Purwokerto RO. The number of students participating in the online tutorial varies for each activity. Out of 28 students, there are $82 \%, 79 \%, 64 \%, 68 \%, 54 \%$, and $43 \%$ students who involved in discussion forum 1, 2, 3, 4, 5, and 6 (Figure 4.3). Furthermore, 64\%, 82\%, and 71\% of the students had submitted assignments at online tutorial assignments 1, 2 and 3 . It clearly show at Figure 2 below.

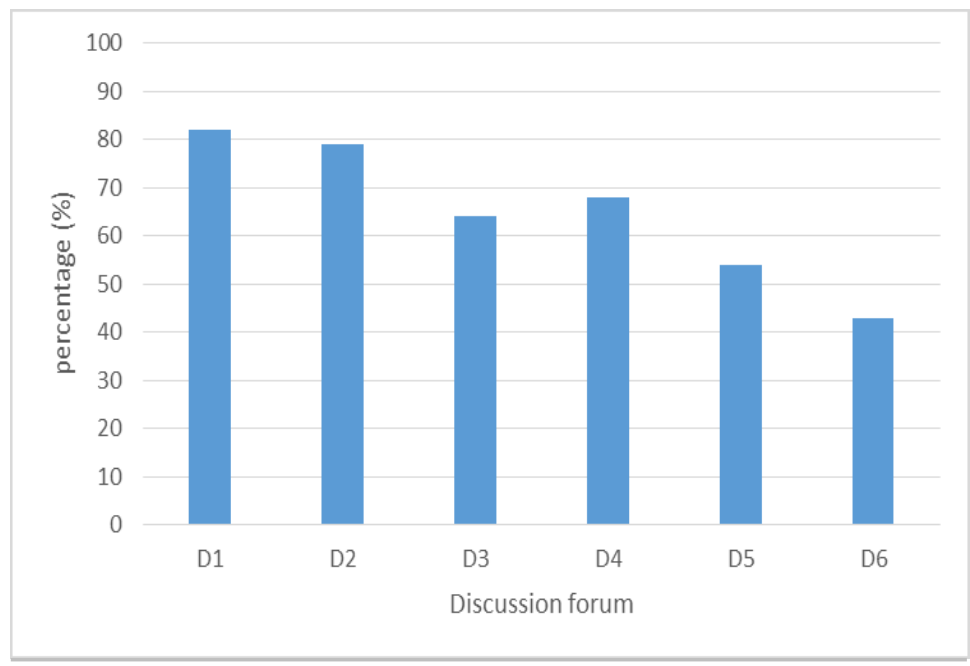

Figure 2. The Number of Students Getting Involved at Every Discussion Forum 


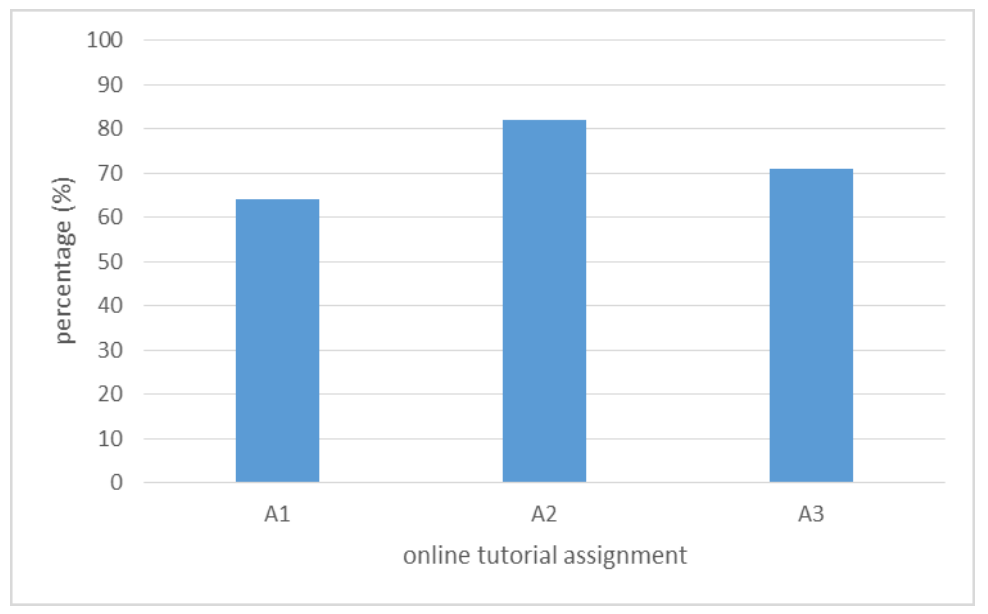

Figure 3. The Number of Students Submitting Assignment at Every Online Tutorial Assignment

The Utility of OER at Online Tutorial

While answering assignment and participating on discussion, the students had already utilized OER besides other resources. About $60 \%$ students utilized OER. However, when the student' answers were analyzed more deeply, it was found that most students had copied the original resource directly. They did not paraphrase the original resources, and did not change the sentences, so the student's answers become too long and wordy. This feature needs attention. Furthermore, in the discussion forums, $48 \%$ students give their opinion or answer based on OER. The rest of them, had used the main learning materials $(26 \%)$ and school books (16\%).

\section{Students' Critical Thinking Achievement at Online Tutorials}

Students' critical thinking achievement in the online tutorial was measured through Tasks. Critical thinking of students was reflected by the answers given by the students. Out of theb12 sub-indicators of critical thinking, four (4) measured through the tutorial assignment, e.q., the sub indicator of considering credibility (source criteria), analyzing argumentation, answering clarification and challenging questions, deciding an action, and identifying assumptions. The abilities of the students were assessed by considering credibility (source criteria) at a high level. Students' ability in analyzing arguments at very high level category. The ability of students in deciding an action at high level category, and the ability of students in identifying assumptions at medium level category. Details are in Table 2 below.

Table 2. Achievement of Students' Critical Thinking Skills for the Online Tutorial of NRCE

\begin{tabular}{|c|c|c|c|c|}
\hline No & Indicator & Sub indicator & & Score \\
\hline 1 & Building basic skills & Consider the credibility (source criteria) & & 74.13 \\
\hline 2 & Providing a simple & Analyze the argument & & 87 \\
\hline 3 & & $\begin{array}{l}\text { Asking and answering clarifying } \\
\text { challenging questions }\end{array}$ & and & 94 \\
\hline \multirow[t]{2}{*}{4} & Setting strategies & Decide on an action & & 77.5 \\
\hline & & Average & & 80.7 \\
\hline
\end{tabular}

The result shows that students' critical thinking skills were of high order. They were strong in providing simple explanations particularly while analyzing the arguments and asking and answering clarifying and challenging questions. However, we cannot see other indicators of critical thinking. It means the tutor of this course needed to refine his/her skills of critical thinking. 
Student Perceptions on the Implementation of OER Based Online Tutorial

Student opinions on the implementation of OER based online tutorial were collected at the end of each online tutorial. Fifteen students returned the questionnaires. The results from the analysis of the data are presented in Table 3.

Table 3. Students' Opinion on the Implementation of OER Based Online Tutorial

\begin{tabular}{llcccc}
\hline \multicolumn{1}{c}{ Statement } & $\begin{array}{c}\text { Strongly } \\
\text { agree }\end{array}$ & $\begin{array}{c}\text { Answer (\%) } \\
\text { Agree }\end{array}$ & $\begin{array}{c}\text { Disagree } \\
\text { Strongly } \\
\text { disagree }\end{array}$ \\
\hline $\mathbf{1}$ & $\begin{array}{l}\text { The materials are interesting } \\
\text { The materials challenge the } \\
\text { students to find other resources } \\
\text { from OER }\end{array}$ & $\mathbf{3 8}$ & $\mathbf{5 4}$ & $\mathbf{0}$ & $\mathbf{8}$ \\
$\mathbf{3}$ & $\begin{array}{l}\text { The materials help students to } \\
\text { express scientific ideas. }\end{array}$ & 46 & 54 & 0 & 0 \\
\hline $\begin{array}{l}\text { The materials could improve skills } \\
\text { in finding and validating } \\
\text { information sources. }\end{array}$ & 54 & 38 & 8 & 0 \\
\hline
\end{tabular}

Thirty-eight percent students strongly agreed, 54\% agreed, and $8 \%$ students strongly disagreed that the materials used in the online tutorial were interesting. Sixty-nine percent students strongly agreed and $31 \%$ students just agreed that the materials had challenged them to find other resources from OER. They found them to be relevant to critical thinking skills, that is, answering clarifying and challenging questions. Forty-six percent students strongly agreed and $54 \%$ students agreed that the materials helped them practice expressing scientific ideas. This is relevant from the view point of developing critical thinking skills, i.e., analyzing the arguments, considering the credibility (source criteria), and deciding on actions. Fifty-four percent students strongly agreed, $38 \%$ agreed, and $8 \%$ disagreed that the materials could indeed improve their skills in finding and validating information sources.

\section{DISCUSSION}

This paper has utilized OER as an open source to conduct online tutorials for NRCE course. OER was utilized by tutors as learning resources / materials while students used OER as a reference in answering the assignment and discussions from the first to the last of the online tutorials. This is in line with the OER practice of including learning resources, resources to support teachers, and resources to assure the quality of education and educational practices (Johnstone, 2005). There are many learning resources available on the internet that can be accessed freely. However, a person or institution needs to join the Creative Commons and Open Course Ware Consortium to save and own their work (Bissel, 2009).

The number of students participating was determine on the basis of questionnaires that had been filled out by students. The students explicitly stated that the resources were provided to complete the online tutorials of NRCE. As for the resources used, $77 \%$ said that it was the internet, $69 \%$ said BMP/modules, $54 \%$ mention other books, $15 \%$ said it was the TV, and $15 \%$ identified them to be from the newspapers. Clearly, OER was the dominant source. Unfortunately, many of the students could not take advantage of OER because of difficulties with composing answers in their own language by referring to OER. This suggested that there was much room for improvement in the utilization of OER as a learning resource in Indonesia. Tutors can deliver OER material beside BMP material, as enrichment material to students on every tutorial. Actually there are many other OERs that can be added to this online tutorial, either OER produced by UT itself (in the form of enrichment material) or other materials taken from other websites. The OER material that can be uploaded by. 
Lecturers or tutors, during active interactions in discussions to support learning (Maboe, 2016). Students who work on group projects together, peer review of their articles, interact in discussion forums, tend to feel more involved in learning (Dixson, 2010). Tutors should consider content and tasks that encourage students to interact with each other. Tutors need to explain the requirements and benefits of interacting. It is not enough to just set up facilities for discussion, for example, by placing announcements on the homepage, e-mails to students, discussion forums in which the instructor interacts, and online lectures or connect sessions and chats, to enhance engagement (Dixson, 2010). The university should teach students how to use online interactive tools to facilitate their teaching and learning, and consider providing intensive mentoring to enable them to utilize the available technologies efficiently (Maboe, 2016).

Learning and teaching approaches that utilize learning by sharing, networking, defining and redefining should be useful. The use of OER is expected to increase the quantity, quality and effectiveness of teaching and learning (Creelman \& Ossiannilsson, 2011). Some instructors do not use OER because (a) they are unaware of copyright issues related to OER implementation, (b) could not find OER relevant to their curricula or their context, or (c) were suspicious of the quality of OER and materials from the internet in general (Mtebe \& Raisamo, 2014). Therefore, tutors should be encouraged to be selfreliant in managing all aspects, including the relevant OER. There is a need to be confident about OER standards or quality criteria selected and used (Creelman \& Ossiannilsson, 2011). One must be sensitive to the legal aspects of each OER used. Therefore, institutions need to prepare clear guidelines so that OERs can be exploited widely, not too carefully but still not against the law. There is an urgent need for university to create awareness of copyright issues in order to enable instructors to adopt OER and share their resources via the internet (Mtebe \& Raisamo, 2014).

In the tutorial for the NRCE course, there was not about what students should be referring to answering questions or discussions. The student could actually select the right material and was trusted (valid) performing the tasks. This was in line with Bissell's (2009) opinion that the digitized OER material can be offered freely and open to educators, students and learners to use in teaching, learning and research. OER offers the following benefits (a) expanding access to learning for all, including non-traditional student groups and people from disadvantaged backgrounds, resulting in widening participation in higher education, (b) providing an efficient way to promote lifelong learning by bridging the separation between non-formal, informal and formal learning, (c) acting as an asset to expand education in developing countries, and (d) offering dramatically new approaches to sharing knowledge that can lead to the economic success of individuals, communities, corporations, and, ultimately, across countries (McDowell, 2010).

Consider now the ability of students to consider credibility (source criteria) and analyze arguments at a high level. It should be remembered that there are differences between the ability of students in deciding an action at a high level category, and the ability of students in identifying assumptions at a medium level. Our results have shown that the critical thinking skills of the students examined were high. The students were quite strong in coming up with a simple explanation particularly with regard to analyzing the arguments and asking and answering clarifying and challenging questions. However, we could not detect other indicators of critical thinking. This meant that tutors of this course should practice other skills of critical thinking. Student attitudes are an important factor in ensuring that they stay engaged with online programs. Attitudes towards the online learning environment also contribute to the value of student participation. In short, student attitudes need to be taken into consideration in designing online learning (Dahalan, Hassan, \& Atan, 2012). 
Most students involved in this study considered that the materials of online tutorial were interesting and suitable for practicing expression of scientific ideas, and agreed that they can help them improve their skills in finding and validating information sources. Moreover most of them perceived that the materials challenge the students to find other resources from OER. This perception was relevant to critical thinking skills, that is, answering clarifying and challenging questions, analyzing the arguments, considering the credibility (source criteria), and deciding on an actions.

\section{CONCLUSION \& RECOMMENDATION}

The development of our model had begun with developing an Online Tutorial Activity Plan and an Online Tutorials Activity Unit by utilizing OER as an additional source of student learning in addition to the Essentials Book as the main source of reading. OER were used in initiation materials, discussion materials and online tutorial task. The results showed that in the online tutorial of NRCE have been able to utilize OER as a learning resource. The students found that the materials helped respond to the discussion material and answer while performing the online tutorial tasks. However, not all students were active or maximal while utilizing OER. This was apparent from the ability of students in selecting reference materials and student learning outcomes. According to indicators of critical thinking ability to analyze, evaluate, and communicate or explain based on the results of this evaluation, $\mathbf{7 0 \%}$ correct. However, some students had not been able to give correct referral addresses and to select the material correctly, therefore could not be trusted (invalid). The results of this study have illustrated that online tutorial activities need to be designed by preparing the proper presentation and place the students at the center as learners. The spread of students across different regions (distance learning) suggest that there will be a variation in the ability of students to use their computer and networking tools, as well as the skills of choosing the right site to get reliable reference materials. This means that online tutorial activities need to be developed always by paying attention to the affordability of students to get access to reading materials and keep abreast of the development of science and technology. Online tutorial activities supported by OER have been responded well by the students. The data of this research meet the purpose of this study.

The main limitations of study basically in the number of respondents and the methods used to activate students. Still the study has suggested, this online tutorial model could be implemented for other courses. However, there should be guidelines for the tutors that can direct students in using the right OER for the purpose/competence of the course to be achieved. Students can use OER as an additional source of reading from the main material provided by the tutors of study program. The tutor should diligently monitor student activities in online tutorial process, particularly for some students who are not yet accustomed to using the computer and network, so that the tutors are able to assist and solve the students' problems. However, this research can indeed be refined through further research, particularly with regard to developing methods used for activating students. There is also room for researches examining how to develop other $21^{\text {st }}$ century skills such as creativity, innovation, collaboration and communication.

ACKNOWLEDGMENT: We would like to extend our sincere thanks to the Directorate of Higher Education Republic Indonesia and Universitas Terbuka that funded our research. We especially thank Dr. Sandra Sukmaning Adji for her comments on our paper. 


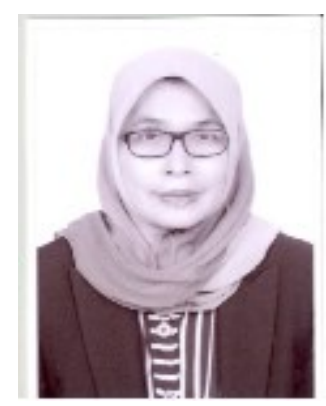

Ucu RAHAYU is a Senior Lecturer at Faculty of Education Universitas Terbuka (UT) Jakarta Indonesia who has more than twenty-five years of experience working for distance teaching university. She earned her Master degree in $\mathbf{2 0 0 0}$ from University of Ottawa, Canada and her Doctor in Science Education from Universitas Pendidikan Indonesia, Bandung, Indonesia. Her academic interest areas are science education, biology education, environmental education, social media analysis, open and distance learning, e-learning and use of internet in education. She has over than $\mathbf{1 0}$ journal articles published in national and international journal and one international book chapters and other national and international papers submitted to the national and international conference.

\section{Dr. Ucu RAHAYU}

Mathematics and Science Education Department, Faculty of Education

Universitas Terbuka, Jakarta, Indonesia

Phone: +62-21-7490941 / 2016

Mobile: +62-81210743162

E-mail: urahayu@ecampus.ut.ac.id

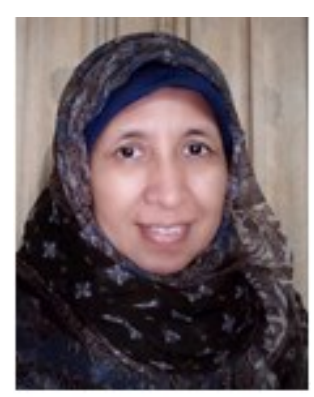

Amalia SAPRIATI is a Senior Lecturer at Faculty of Education Universitas Terbuka (UT) Jakarta Indonesia who has more than thirty years of experience working for distance teaching university. She earned her Master Degree in 1993 from University of Victoria, B.C., Canada and her Doctor of Educational Research and Evaluation in 2006 from Universitas Negeri Jakarta, Jakarta, Indonesia. Her main area of research interest is assessment and evaluation of learning for distance higher education, as well as science education. She has over than 8 journal articles published in national and international journal and other national and international papers submitted to the national and international conference.

\section{Dr. Amalia SAPRIATI}

Mathematics and Science Education Department, Faculty of Education

Universitas Terbuka, Jakarta, Indonesia

Phone: +62-21-7490941 / 2451

Mobile: +62-81291719011

E-mail: lia@ecampus.ut.ac.id

\section{REFERENCES}

Arendt, A.M., \& Shelton, B. (2009). Incentives and Disincentives for the Use of Open Course Ware. International Review of Research in Open \& Distance Learning, 10(5), 1-25.

Alexander, M.E. et.al. (2010). Using the four-question technique to enhance critical thinking in online discussions. Merlot Journal of Online Learning and Teaching, 9(2), $409-415$

Basham, G. et.al (2008). Critical thinking a student's introduction. Boston: McGraw-Hill.

Bissell, A.N. (2009). Permission granted: open licensing for educational resources. Open Learning, 29(1), 97-106

BSNP. (2013). Paradigma pendidikan nasional abad XXI versi 1,0. Badan Standar Nasional Pendidikan. 
Borg, W. R., \& Gall, M. D. (1989). Educational research. An introduction (5th ed.). White Plains, NY: Longman.

Case, R. (2005). Moving critical thinking to the main stage. Education Canada, 45(2), 4549. Pithers and Soden (2000) reject the view that critical thinking could be taught as a separate

Creelman, A., \& Ossiannilsson, E. (2011). Quality indicators within the use of open educational resources in higher education. Education in a technological world: communicating current and emerging research and technological efforts. A. Méndez-Vilas (Ed.): 372-382

Dahalan, N., Hassan, H., \& Atan, H. (2012). Student engagement in online learning: Learners attitude toward E-Mentoring. Procedia-Social and Behavioral Sciences, 67, 464-475.

d'Antoni, S. (2006), 'Open Educational Resources: Deliberations of a Community of Interest'. Presentation ICDE SCOP Meeting, 11-13 June 2006, Lillehammer, Norway. See URL ICDE

Dixson, M.D. (2010). Creating effective student engagement in online courses: What do students find engaging? Journal of the Scholarship of Teaching and Learning, 10(2),1-13

Ennis, R. H. (1985). A logical basis for measuring critical thinking skills. Educational Leadership, 43(2), 44-48.

Ennis, R. H. (1989). Critical thinking and subject specificity: Clarification and needed research. Educational Researcher, 18(3), 4-10.

Ennis, R., H. (1996). Critical Thinking. Upper Saddle River, New Jersey: Prentice-Hall Inc.

Facione, P. A. (1990). Critical thinking: A statement of expert consensus for purposes of educational assessment and instruction. Millbrae, CA: The California Academic Press.

Halpern, D. F. (1998). Teaching critical thinking for transfer across domains: Dispositions, skills, structure training, and metacognitive monitoring. American Psychologist, 53(4), 449-455.

Hibbard, S.T., Bellara, A.P, and Vermette, P. (2010). Evaluating the use of online discussion boards for pre-service teacher Learning. The International Journal of Learning, 176), 175 - 186

Johnstone, S.M. (2005), 'Open Educational Resources serve the world'. Educause Quarterly, 3, 15-18.

Kanwar, A. And Uvalic-Trumbic, S. (2011). A basic guide to Open Educational Resources (OER). Retrieved on July 24, 2012 from http:// www.pustaka.ut.ac.id/ pdfebook/eb074.pdf

Kogut, L.S. (1996) Critical thinking in general chemistry. J.Chem. Educ., 73(3), 218-221.

Lin, S.S. (2013). Science and non-science undergraduate students' critical thinking and argumentation performance in reading a science news report. The International Journal of Science and Mathematics Education.

Maboe, K.A., 2016, "Online communication of health studies students: Perspective of Open Distance Learning" Health SA Gesondheid 22 (2017): 221 - 227

McDowel, E.A. (2010). Using open educational resources to help students understand the sub-primelending crisis. American Journal of Business Education, 3(11). 85-92. Abstract Tagged XML BibTex Google Scholar Download: 66-256-1-PB.pdf

Mtebe, J. S., \& Raisamo, R. (2014). Challenges and instructors' intention to adopt and use open educational resources in higher education in Tanzania. The International Review of Research in Open and Distributed Learning, 15(1). 
Osborn, J. (2007). Science education for the twenty first century. Eurasia Journal of Mathematics, Science and Technology Education, 3(3), 173-184.

Paul, R. W. (1992). Critical thinking: What, why, and how? New Directions for Community Colleges, 1992(77), 3-24.

Pithers and Soden (2000). Critical Thinking in Education: A Review. Educational Research, 42(3), 237-249

Risch, J.K., Jackson, P.C., and Murray, M.C. (2013). WikiED: Using web 2.0 tools to teach content and critical thinking. Journal of College Science Teaching, 3(1), 70 -80.

Sternberg, R. J. (1986). Critical thinking: Its nature, measurement, and improvement National Institute of Education. Retrieved from http://eric.ed.gov/PDFS/ ED272882.pdf.

Stiggins, R.J. (1994). Student-Centered Classroom Assessment. Nem York. Macmillan College Publishing Company. Inc.

UNESCO (2002) Forum on the Impact of Open Courseware for Higher Education in Developing Countries. Final Report. http:// unesdoc.unesco.org/images/0012/ 001285/128515e.pdf (accessed 11 January 2018)

Willingham, D. T. (2007). Critical thinking: Why is it so hard to teach? American Educator, 819. 